Meyer, A. (1944). Z. Vitaminforsch. 14, 322.

Meyer, K. (1945). Advanc. Protein Chem. 2, 249.

Partridge, S. M. (1948). Biochem. F. 43, 387.

Penney, J. R. \& Balfour, B. M. (1949). F. Path. Bact. 6r, i 7 I.

Persson, B. H. (1953). Studies on Connective Tissue Ground Substance. Uppsala: Almqvist and Wiksells.

Reddi, K. K. \& Nörstrom, A. (1954). Nature, Lond., 173, 1232.

Routh, J. I. (1938). F. biol. Chem. 123, civ.

Rudall, K. M. (1952). Advanc. Protein Chem. 7, 253.

Sizer, I. W. (1949). Enzymologia, 13, 288.

Sylven, B. (1956). In The Biochemistry and Physiology of Bone [G. H. Bourne, editor]. New York: Academic Press.

\title{
A comparative study of the diets, and results of some blood analyses, of children living in different environments in Jogjakarta (Central Java)
}

\author{
BY YAP-KIE-TIONG \\ Yap Ophthalmic Hospital, Jogjakarta, Indonesia
}

(Received 15 October 1956)

The majority of the people living in the Jogjakarta area (Central Java) suffer from a type of chronic malnutrition which generally does not interfere with their ability to perform heavy labour. Studies of the eye changes in this type of chronic malnutrition have led to a comparative study of the diets and blood chemistry of children living in different economic environments. The chemical values can only be considered within certain limits as reliable in the appraisal of the nutritional status, owing to the possible presence of chronic infectious diseases such as malaria and intestinal worms, yet it seemed useful to carry out this comparative study in order to obtain a 'normal' local pattern. The investigation comprises $(a)$ a study of the food intake of groups of children living in different economic environments, and $(b)$ the determination of the concentration of serum albumin and globulin, and the levels of haemoglobin, vitamin $A$, carotene and calcium in the blood.

\section{EXPERIMENTAL}

Subjects. The boys and girls who were the subjects of this study were drawn from three groups: (I) twenty-five doctors' children, aged 6-17 years (mean 12 years); (2) thirty-three children living in an orphanage (not all orphans), aged 6-1 8 years (mean I4 years); (3) twenty-one children, aged 6-18 years (mean 13 years) living in a poor subdistrict of Jogjakarta, where the people show obvious stigmata of malnutrition. All children were of Indonesian origin.

Diet. The staple food of all the children was rice, the doctors' and the orphanage children having about $35^{\circ}$ and the poor-area children about $175 \mathrm{~g}$ daily. The customary diet of the doctors' children included legumes, nuts, soya-bean products, 
vegetables and fruits and sufficient meat, fish and eggs. The diet of the orphanage children contained reasonable amounts of legumes, soya-bean products, vegetables and fruits but was lacking in protein and fat of animal origin, containing only very small amounts of meat, eggs or dried salted fish; the principal fat was coconut oil. The poor-area children ate a larger proportion of starchy foods such as tubers and roots, since they had only about half the amount of rice the other two groups had; their diet included tubers, roots, pulses, soya-bean products, coconut, green vegetables and very small amounts of meat or dried salted fish.

The food intake of each child was measured by weighing over a period of 7 days, and the mean intakes of calories and nutrients in each group were calculated from food tables compiled by the Institute of Nutrition at Djakarta. This diet survey was done by one dietitian.

Laboratory methods. Blood samples were obtained from an arm vein. Blood determinations were made by two laboratory technicians, one responsible for the protein, vitamin A and carotene estimations, the other for the haemoglobin and calcium estimations. Serum proteins were measured by the biuret method of Gornall, Bardawill \& David (1949), the biuret colour being read on a Spekker photoelectric colorimeter (Hilger and Watts Ltd, London). Haemoglobin was measured colorimetrically by the method of Sahli-Hellige, with a Zeiss haemometer. Vitamin A was measured by the photo-colorimetric method of Dann \& Evelyn (1938) and calcium by the method of Clark \& Collip (I925).

\section{RESULTS AND DISCUSSION}

Table I gives the mean intake of calories and nutrients in each group. The mean results of the blood determinations are shown in Table 2.

Table I. Comparison of the mean nutritive value of the daily diet of three groups of children living in different economic circumstances

\begin{tabular}{|c|c|c|c|}
\hline Nutrient & $\begin{array}{c}\text { Doctors' } \\
\text { children }\left(\mathbf{2 5}^{*}\right)^{*}\end{array}$ & $\begin{array}{c}\text { Orphanage } \\
\text { children }(33)^{*}\end{array}$ & $\begin{array}{c}\text { Poor-area } \\
\text { children }(2 \mathrm{I})^{*}\end{array}$ \\
\hline Calories (Cal.) & 2218 & I 473 & 1271 \\
\hline Total protein (g) & 63 & 39 & 28 \\
\hline Animal protein $(g)$ & 24 & $0 \cdot 2$ & 0.5 \\
\hline Fat $(\mathrm{g})$ & $5^{8}$ & II & 21 \\
\hline Carbohydrate (g) & 363 & 299 & I 39 \\
\hline Iron (mg) & 25 & 29 & 9 \\
\hline Calcium (mg) & 254 & 99 & 139 \\
\hline Vitamin A (i.u.) & 700 & 4 & 4 \\
\hline Carotene (i.u.) & 2805 & 4 I 55 & 805 \\
\hline Thiamine (mg) & $1 \cdot 0$ & 0.8 & 0.7 \\
\hline Ascorbic acid (mg) & IOO & I75 & 59 \\
\hline
\end{tabular}

The food intake of the group of doctors' children agrees very well with the requirement standards suggested by Nicholls (195I) for children of the same age range under tropical conditions. The intakes of the orphanage children, and even more those of the poor-area children, were, however, extremely low. 
The mean total serum-protein content found in the group of doctors' children was $7 \cdot 4^{2} \mathrm{~g} / \mathrm{r} 00 \mathrm{ml}$. with an albumin:globulin ratio of $\mathrm{I} \cdot 39$. The group of orphanage children showed a mean total-protein concentration of $7.3 \circ \mathrm{g} / \mathrm{ro0} \mathrm{ml}$. and an albumin: globulin ratio of $\mathrm{I} \cdot 08$, whereas in the group of poor-area children a mean total-protein content of $6.90 \mathrm{~g} / 100 \mathrm{ml}$. was found with an albumin:globulin ratio of 0.98 . The drop in the total-protein content in these two groups, being mainly that of the albumin fraction with a reversal of the albumin: globulin ratio, seems to have been due to the low protein intake, 39 and $28 \mathrm{~g}$, in turn obviously associated with the low calorie intake.

Table 2. Comparison of mean serum protein and blood haemoglobin, calcium, vitamin $A$ and carotene levels in three groups of children eating diets shown in Table I

$\begin{array}{lccc} & \begin{array}{c}\text { Doctors' } \\ \text { children (25)* }\end{array} & \begin{array}{c}\text { Orphanage } \\ \text { children (33)* }\end{array} & \begin{array}{c}\text { Poor-area } \\ \text { children (2I)* }\end{array} \\ \text { Serum: total protein (g/100 ml.) } & 7.4 & 7.3 & 6.9 \\ \text { albumin (g/100 ml.) } & 4.3 & 3.8 & 3.4 \\ \text { globulin (g/100 ml.) } & 3.1 & 3.5 & 3.5 \\ \text { Haemoglobin (g/100 ml.) } & 13.3 & 10.6 & 8.2 \\ \text { Calcium (mg/roo ml.) } & 10.6 & 9.5 & 8.5 \\ \text { Vitamin A (i.u./100 ml.) } & 149 & 77 & 67 \\ \text { Carotene (i.u./100 ml.) } & \text { I63 } & 136 & 44 \\ & * \text { Number in group. } & \end{array}$

The mean blood haemoglobin level was $13.3 \mathrm{~g} / \mathrm{roo} \mathrm{ml}$. in the group of doctors' children, $10.6 \mathrm{~g}$ in the orphanage children, and $8.2 \mathrm{~g}$ in the poor-area children. The diet of the poor-area children, although supplying $9 \mathrm{mg}$ iron/day, was defective in many respects and may have played an important part in the aetiology of the anaemia in this group.

The calcium level of the serum of the doctors' children was $10.6 \mathrm{mg} / \mathrm{r} 00 \mathrm{ml}$, very similar to the level generally accepted as normal, about $10 \mathrm{mg} / \mathrm{I} 00 \mathrm{ml}$. The calcium intake, however, was far below the level usually recommended. The group of orphanage children had a still lower calcium intake, and the mean calcium content of their serum was $9.5 \mathrm{mg} / 100 \mathrm{ml}$. The group of poor-area children, with the lowest mean daily intake of calcium, had a mean serum calcium concentration of only $8.5 \mathrm{mg} / 100 \mathrm{ml}$. Although the calcium intake of the poor-area children was higher than that of the orphanage children, the calcium level of the serum was lower.

The mean vitamin A level in the serum of the doctors' children was 149 i.u./100 $\mathrm{ml}$., higher than the mean level found by Yudkin (r94I) in normal adults. This author found levels ranging between 72 and 157 i.u. with a mean of $I_{1} 3$ i.u. in twenty-three subjects with normal dark adaptation. The daily intake of 700 i.u. vitamin A and 2805 i.u. carotene satisfies internationally recommended standards of intake for children. The group of orphanage children showed a mean vitamin A level of 77 i.u./ roo ml. serum with a daily intake of 4 i.u. vitamin $A$ and 4155 i.u. carotene. A mean vitamin $A$ concentration of $67 \mathrm{i}$.u. was found in the serum of poor-area children, and the mean daily consumption was only 4 i.u. vitamin $A$ and 805 i.u. carotene. The vitamin $A$ levels in the serum of the orphanage and poor-area children were high in relation to the low vitamin $A$ intake and reflect conversion of the consumed carotene into vitamin A. 
The mean carotene levels in the serum were: doctors' children 163 , orphanage children 136 and poor-area children 44 i.u./100 ml. Yudkin (I94I) reported values between $5^{\circ}$ and $24 \mathrm{r} \mu \mathrm{g}(83$ and 402 i.u.)/ $100 \mathrm{ml}$. serum in normal adults.

The blood findings and the results of the diet survey, with the exception of the calcium intake, in the group of doctors' children help to confirm that this group was 'well' nourished according to present-day nutritional standards. The calcium intake of $254 \mathrm{mg}$ was at a considerably lower level than is generally recommended.

The following questions consequently arise: Was this calcium intake too low, or does some biological adaptation exist so that this calcium intake may be regarded as 'normal' in relation to the local conditions? Are the calcium intakes generally recommended unnecessarily high for people living under tropical conditions?

The low blood values and the inferior nutritive value of diets of poor-area children suggest relative nutritional deficiency.

The diet of the group of orphanage children, with its low values for calories, proteins-especially proteins of animal origin-calcium and vitamin A, was very similar to the average diet customary in the Jogjakarta area. If the biochemical findings in the blood are a reflexion of nutritional status, and if the effects of any possible presence of chronic infectious diseases, as for instance malaria or intestinal worms, are ignored, the blood values in the group of orphanage children may be considered as representative of children suffering from the type of chronic malnutrition endemic in the Jogjakarta area.

\section{SUMMARY}

I. In order to throw further light on nutritional standards in Jogjakarta (Central Java) a comparative study was made of diet and biochemical blood findings with seventy-nine children living in three different economic environments.

2. The intake of energy and nutrients, with the exception of calcium, and the level of serum protein and of blood haemoglobin, vitamin $A$, carotene and calcium, in the group of doctors' children conformed to generally accepted levels of normality. The significance of the relatively low calcium intakes found in all groups is discussed.

3. The nutritive value of the diet and the low blood values found in the group of children from a poor area indicated a deficiency state.

4. Children living in an orphanage and consuming a diet very similar to the average diet customary in the Jogjakarta area, with relatively low intakes of calories and nutrients, showed blood levels that may be considered as characteristic of children suffering from the type of chronic malnutrition endemic in the Jogjakarta area.

The author is greatly indebted to Miss Sukartyah, Jogjakarta, for the diet survey made in this study, and to Dr Mardjaban Purwodhiredjo, Jogjakarta, for his cooperation.

\section{REFERENCES}

Clark, E. P. \& Collip, J. B. (1925). 7. biol. Chem. 63, $46 \mathrm{r}$.

Dann, W. J. \& Evelyn, K. A. (1938). Biochem. F. 32, 10o8.

Gornall, A. G., Bardawill, C. J. \& David, M. M. (1949). F. biol. Chem. I77, 75 I.

Yudkin, S. (r94I). Biochem. F. 35, 551 .

Nicholls, L. (1951). Tropical Nutrition and Dietetics, 3 rd ed. London: Baillière, Tindall and Cox. 